\title{
The Declaration of London and our Food Supplies
}

\section{Douglas Owen Esq. \& Admiral Sir Cyprian A.G. Bridge In the Chair G.C.B.}

To cite this article: Douglas Owen Esq. \& Admiral Sir Cyprian A.G. Bridge In the Chair G.C.B. (1911) The Declaration of London and our Food Supplies, Royal United Services Institution. Journal, 55:396, 149-185

To link to this article: http://dx.doi.org/10.1080/03071841109425487

\section{曲 Published online: 11 Sep 2009.}

Submit your article to this journal $\pi$

Цll Article views: 4

Q View related articles $\sqsubset$ 


\title{
THE DECLARATION OF LONDON AND OUR FOOD SUPPLIES.
}

\author{
By DOUGLAS OWEN, Esq.
}

On Wednesday, 18th January, 1911.

Admiral Sir Cyprian A. G. Bkidge, G.C.B., in the Chair.

IN 1899 the Czar of Russia brought about a Conference at the Hague for the reduction of armaments: It was, of course, a failure. Out of it, however, grew the Hague Conference of 1907. Out of this, again, grew a proposal for the formation of an International Court of Appeal against decisions of National Prize Courts: : But clearly the first thing needful for such a Supreme Court of Appeal must be an accepted basis for its decisions. In order, therefore, to draw up a code of prize laws of universal acceptance it was agreed to call yet another Conference. At this Conferenoe, known as "The International Naval Conference," held in London in 1908, a code was drawn up, a code now known as the Declaration of London. This code is what we have to-day to consider : solely. however, from the point of view in which it will affect our fund supplies in time of war. I wish to emphasise this, in order that in any discussion which may take place the fact may lee especially borne in mind. The Declaration in other aspects is no part of our subject.

Now, to give effect to the Declaration, a Naval Prize Bill has been introduced into Parliament; and in the Bill, yet to be passed, an International Court of $\Lambda$ ppeal is recognised as part of our Prize law process. The Declaration itself, as such, is not open to Parliamentary discussion, but only as part of the machinery of the Naval Prize Bill. If the Bill is passed, the Declaration of London will be binding on us. If the Bill be thrown out or withdrawn, then, as I imagine, the provisions of the Declaration will fall to the ground.

My object to-day is to demonstrate that, from the point of view of our Food Supplies at any rate, the proposed incorporation of the Declaration of London in the Naval Prize Bill necessarily and inevitably demands rejection of that Bill.

The Two View's of the Declaration.

There are two views of the Declaration : one, that in which Great Britain is a neutral looker-on at the hostile operations 
of other States; the other, that in which Great Britain is herself one of the belligerents. There is of course the very widest difference between the two views. The interests involved when we are merely lookers-on are essentially pecuniary interests, and those of only a limited, if important, class. The interests involved when we are at war will be those of every man and woman not merely in the country, but in the Empire. The matter will be one of the nation's very existence; of its life and death. It is true that, under the first aspect, the present divergent views of naval prizc law may on occasion result in injury to individual traders and so create friction between us as neutrals and a high-handed belligerent Powcr. As a matter of fact and experience, however, we have not allowed the grievances of individual traders to force us into war, and it is certainly the fact that, in spite of the divergencies of which we hear so much from jurists, our maritime trade has attained a boundless prosperity: I feel sure you, will agree, with me that if the maritime traders had in their own interests tried of them-. selves to induce the Government to get, our understanding of naval prize law set aside, the Government would have been in a position to declare convincingly that the grievances of the trackers were not such as to call for the machinery of an international conference to right them. . However, we need not: argue this; for, as a fact, the traders of this country, setting their country's safety before any interests of their ou'n, have, practically with one voice cried out against the Declaration. The. Chambers of Commerce of London, of Liverpool and Glasgow, and I know not how many more, have individually, after. carefully considering the Declaration, protested vehemently. against it. They found that, however it might be supposed to benefit themselves, it was, in fact, opposed to the interests of the country. And what is bad for the bee-hive cannot br beneficial to the bee.

Thf Old Conntrions and the New.

In his letter of instructions to our Delegates, Sir :Edward Grey laid stress on the fact that the passing away: of the old sailing-ship conditions should enable us to go back to "first principles": (whatever these may be) and formulate uniform laws accordingly. But it is not merely that old conditions have passed away.: New conditions have arisen which seem to ne to be absolutely fatal to any scheme of uniformity. And notably our modern and aluays increasing dependence on overseas food-four loaves out of every five we eat; half of our meat, butter, poultry, and cheese; and so on. Now, these new conditions are such that it is practically impossible for us and the Continental States to take, in any new scheme of naval prize laws, one and the same view. The well-intentioned Delcgates attempted the impossible. They engaged in an amiable plan to mix oil and siater. The mixture may or may not be good for the Continental States: for us it is pernicious. 
The Continental States are largely, as at one time was the case with us, self-supporting. Owing, however, to their geographi-. cal position, for any supplies they may need they are not, like us, dependent on the seas. They can nowadays obtain their supplies (thanks to the modern conditions of inland transport) from contiguous States or through neutral ports. At this very day, in peace, Germany does in fact obtain some three-fourths of her overseas corn through Rotterdam-and Antwerp. In our wars of former days we used to blockade the ports of a Continental enemy in order to inflict on him inconvenience and distress. The new conditions have drawn our teeth so far as this weapon is concerned. The Treaty of Paris, too-another modern condition-enables our enemy to carry on his trade under the neutral flag, and so obtain his supplies in neutral vessels through any of his ports which are not blockaded. However, let us return to the altered conditions as regards Great Britain's food supplies: a question which our peculiar circumstances make absolutely vital to us.

\section{Our " Heel of Achilles" : Panic.}

The outbreak of war always, I believe, sends up the price of wheat, and may do so greatly. Undoubtedly the outbreak of a war in which we were engaged nould immediately or, more probably, in anticipation, create not only a serious rise, but also the general expectation of further advances. Immediate purchases by the trade generally would result. In addition, the mere possibility or, as many would think, the probability of hostile interference with our supplies, and the certainty of high or even famine prices, would create a popular run on all the wheat and flour and foodstuffs in the country. The Royal Commission on Food Supplies believed that at the outbreak of har we should have at least 61 weeks' supply of breadstuffs in the country. That is to say, of course, 6. weeks' supply for a normal demand. But how if the demand were a panic demand? An eminent Corn Trade witness expressed the opinion that the rush would be such as to clear the market in a day or two. This simultaneous and excessive demand would of necessity cause a very rapid rise in prices. These prices only the well-to-do would be able to pay, and a food panic would seize the masses, the panic itself driving up prices to a figure utterly beyond the reach of the working classes, many of them rendered wageless by the war. Our own common sense and knowledge of cause and effect can leave us with no doubt upon the subject. A bank panic, with waiting crowds in the streets all night, is as nothing to a food panic which itself creates the shortage on which the fear of it is founded. Of an actual shortage created by the hostile operations of the enemy I have less fear. But if the markets of the poor be swept clean of food, as $I$, in common. with the Corn Trade experts apprehend they will he, the food of the masses will be as effectually cut off as if the enemy had intercepted it. A year 
ago I was privileged to read in this room certain proposals which rould prevent or diminish panic by the creation of a public confidence in the measures which would, under the proposals which I outlined, be resorted to; measures to divert to us supplies which would be ample. Now comes this Declaration of London gratuitously exposing our vital food supplies to terrible new, risks. if the object of the Conference had been to create and stimulate a pritish food panic in time of war, it could hardly have been more ingeniously conceived.

Panic is what we have especially to fear. The Royal Commission, in ominous language, plainly warned us of it; a food panic which at a most critical moment in our history, might fatefully interpose between the Government and the exercise of its plan of warlike strategy. I could quote niany passages from the evidence before, and the Report of, the Food Commission to prove this to the hilt, if nced be. We have had food shortages in the past, with riotous mobs parading the,roads and streets, pillaging granaries and food stores, blackmailing frightened tradesmen; wrecking and destroying. Even in the Crimean war, with the price of the loaf at only rod. or I Id., at Liverpool, in the East End of London and elsewhere, food shops were pillaged and their occupants blackmailed for money. In the Napoleonic wars we were self-supporting, and yet bread remained for weeks at eighteenpence the loaf. What the price might rise to, with, as is the case to-day, four-fifths of our.bread imported and the enemy's commerce destroyers taking to the seas, it is impossible to say. And.whereas, in the old days, be they as resentful as they might of the hardships of war, the masses had practically no effective influence on the policy of the Government, all. this to-day is changed. With a -labour Press, an important labour representation, and infuential labour unions, the masses to-day can speak with jno uncertain voice. And what so likely to stir them to the core as a deficiency or high cost of their daily, bread? Panic will be our danger; and in the face of panic it is useless to quote facts and arguments to the panic-stricken. There, are optimistic persons who seck to re-assure themselves and us by their conviction that a panic "would not last long." Perhaps not. It is the nature of a panic, as of an avalanche or tidal wave, to be short and sharp. It is the consequences, which are important. And when the panic, like a sudden, devastating storm, has spent itself, and bread is still, or possibly, more than ever, at starvation prices, what then? It.must be a sanguine disposition which will find much ground for re-assurance in the belief or hope that the panic "Won't: last:long." . But what is the assurance that a panic.or at all events a dire anxiety, uill not last long? Don't let us be under any illusions. :Our enemy will have an altogether-new and deadly weapon to use against us : the cutting off of our frod supplies. He will choose his:time, his fast cruisers and..converted mail steamers vill adrertise their 
presence off the ports from which ,corn, is shipped to us, and on the trade routes which such shipments follow, and there will be panic, or something very like it, amongst the shippers also. The trade will come to a stop, the duration of this stoppage being dependent on the effectiveness of our patrol and preventive measures, an all-important problem in itself. What right, then, have we to console ourselves with the confidence that a panic or a food anxiety "won't last long"? But even thase who may remain of this belief are hardly likely to find in it any argument for an international convention which will of itself increase the risk of panic. And that the Declaration of London will increase this terrible national danger at.a moment most critical, when the Government will require the utmost calm and self possession, I am presently going to -show.

This danger of a working-class panic, with all its farreaching possibilities, is peculiarly our weak.spot, our Achilles' Heel. And is it for a moment to be supposed that on the outbreak of war our enemy will not make it his special object to send his deadly arrow into it? It will assuredly be given a front place in his warlike strategy. Anything that he can do to distract our Government and war-lords by promoting or fanning the apprehensions of the hunger-fearing masses, ithis we may depend on him to do. And the Declaration of London will lend him powerful aid.

\section{A Fatal Oversight.}

The old sailing-ship and pre-telegraph conditions have, as we well know, and as Sir Edward Grey was at pains to remind our Delegates, quite passed away. 'But they have not merely passed away: they have; in fact, been driven out by modern progress and developments. And the sheet is not: left blank by the disappearance of the old conditions; it is black with the heavy writings of the new. In peace or in war, these new conditions affect us and others in a variety of ways. But in war, broadly stated, they strengthen the position of our enemy, they give him safety where formerly he was vulnerable, and more especially, they expose in us, as we have just been seeing, a new and deadly weakness. In his instructions for the Second Hague Conference (1907) Sir Edward Grey thought it expedient to remind our Delegates of this, himself. "It is essential to the interests of Great Britain," he wrote for their guidance, "that every effective measure necessary to protect the importation of food supplies and raw materials for peaceful industries :should be accompanied by all the sanctions which the law. of nations can supply." This was his caution to our Delegates at the Sccond Conference. $\cdots$ It was not much, in view of all the facts; but at any rate it was something. It is, however, a remarkable: and lamentable fact that in the letter of instructions to our Delegates at the Third or I.ondon. Conference even this mild warning was omitted. Our Delegates were sent to this 
fateful Conference with the predominant idea that uniformity in naval prize law was the great object of the Conference; and that the passing of the old conditions was all in favour of a blessed uniformity. Uniformity was the essential thing. On the substitution of the new conditions, and especially on the transcendent necessity for agreeing to nothing which would hurt us through our food supplies in the event of war, I find in the blue book not one single word. The warning deemed. necessary for the Delegates at the Second Conference was apparently. omitted in the instructions to the Delegates at the Third : a vital oversight. And as a fact, in the special report of our Delegates, I find not one word to indicate that in the momentous changes to which they had agreed, in the cause of uniformity, our new danger was, as assuredly it should have been, foremost in their thoughts. I find nothing, indeed, to show that it was in their thoughts at all.

And now let us turn to the Declaration and see how, in its aim for uniformity, in its anxiety for the interests of neutral commerce, it imperils our food supplies in time of war, and aggravates that danger of a far-reaching national food punic which it should be our most anxious thought to prevent or minimise.

The Existing Law and the Declaratjon Law.

The decisions of the British. Prize Courts have hitherto asserted the law that a foodstuffs cargo in neutral vessels is, as regards voyage, liable to condemnation "only if there is proof that its destination is for the naval or military forces of the enemy, or for some place of naval or military equipment in the occupation of the enemy." (Int. Nav. Con., p. 4, par. 4,)

The Declaration introduces a new and different law, and greatly to the prejudice of the British food supplies. Thus :-

I. The destination as above defined is presumed to exist if the cargo is consigned to a contractor (dealer). who as a matter of common knowledge supplies such articles to the enemy. (? Enemy's forces; though the word is "enemy."). (Art. 34.)

2. Similarly, if the place of destination serves as a base for the enemy's armed forces. (Art. 34.)

Now $\mathrm{I}$, in common with weighty and responsible critics of the Declaration, maintain, and maintain with confidence, that these new provisions are charged with most dangerous consequences. Those whose business and responsibility it is to defend the Declaration deny that the words can have the meaning or effect that rie attach to them. Possibly when those responsible to the country assented to the phraseology, they did not attach to it the meaning which we place upon it, and it is no less possible that they may still recognise in the uording only the sense of their own intention. We all know, however, how often. 
it has happened that our Courts of Justice have had to interpret statutory sections in a sense said to be foreign to the. intention of the framers. Those responsible for the Declaration are, in fact, in a very difficult position, and their only defence can be and is that the critics-the practical, impartial and, many of them, very able critics-of the Declaration place on the kording a meaning which it was not intended to bear and does not bear. The critics, on their part, take their stand on the wording solely, and reiterate the justice of their protests. But it is, alter all-or, if not, it certainly should bejust a matter of plain English, and you should be as weif qualified to judge of the meaning as either clisputant. In any. case I am sure of your agreement that in an international declaration of the very first importance to this country, a difference of opinion, at the very outset, as to the meaning of a fundaniental clause, is little short of tragic. I think that even those responsible for the Declaration will admit that if the International Court should interpret the wording in the sense put upon it by its adverse critics this would be most serious for our country. That we should expose the country to such a risk, in the hope

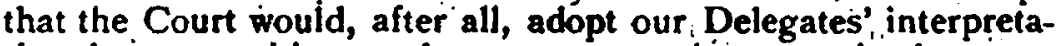
tion, is a proposition not for a moment to be entertained.

The Novel "Government Contractor" Law.

The cargo is presumed to be destined for the enemy's-say, for our-armed forces if consigned to a contractor-a word supposed to mean, in the context, "dealer "-who, as a matter of common knowledge, supplies such articles to the enemy; by which word again is supposed to be meant the enemy's armed forces. It is rather sad to have to rely, in a momentous document of this kind, on suppositions for its interpretation; but let that pass. Now I want you particularly to bear in mind this fact: that while no ship or cargo can be condemned by a Prize Court except for breach of the law, practically any ship can be captured in order that it may be determined by a Prize Court whether her voyage was illegal or was not. She will then eventually be either condemned or released as the facts may warrant. But if she be released, the question will arise whether in the circumstances the action of the captor was justified. $\Lambda n$ irregularity in the ship's papers, or the failure of the captain to satisfy the reasonable enquiries of the visiting naval officer, or other circumstances which might create a reasonable suspicion on the part of the belligerent, will justify the capture; and though the captured ship may in such a case eventually be released. she will get no compensation, but will have to bear all her own expenses and in addition the captor's costs. If it should be found that the ship was free from suspicion and that her capture was unjuistified or unreasonable, then, on her eventual release, the raptor will have to pay compensation. The point I want you to hear in mind throughout is that many ships may quite seasonably and justifiably be captured only, perhaps, to the vol. Lv. 
eventually released; but that if cuptured because of irregularity in the papers or because of want of proper intornation on the part of the captain respecting either the nature of his cargo; or, under the Declaration Law, at any rate, its ounership of inland destination; then the ship, though released, must be held to blame for her own capture.

And now see the eficct of the new law that a neutral ressel carrying food.to a purt of peaceful consumption shall be liable to capture for. adjudication if her captain cannot show that her cargo is not going to a person in the habit of supplying the Government with foodstuffs. 'The visiting ofticer trom id ship of our enemy boards the vessel, exanines her papers and asks the capiain who is the ouner of the cargo: is it going to a Government contractor? Now, wheat cargoes are sold over and over again between the sailing of the ship and her.arrival, ownership of the cargo passing by transfer of the bills of lading and policies of insurance. How, then, can the captain possibly know? In ninety-nine cases out of a hundred he will have to confess to the visiting officer that he cannot answer the question. "Well," says the officer, " you ought not only to know, but your documents ought to contain credible evidence upon the point." The officer will reasonably and justifiably capture the ship, or even, as we shall see presently, he may sink or burn her.

In his letter of instructions to our Delegates, Sir Edward Grey remarked that "what the commerce of the world above all desires is certainty" ; and that "the widest possible freedom for neutrals in the unhindered navigation of the seas" should be the object of the Delegates. : What sort of certainty, what sort of freedom in navigation, does this new rule confer on neutrals.

But let us pause a moment here to notice this :-Sir Eduard Grey says that the Declaration exposes to condemnation no foodstuffs not already so exposed. Quite inaccurate! $\Lambda$ dealer who supplies the Government is also and primarily a dealer who supplies the trade. This new law exposes to condenination foodstuffs going, for popular consumption, to a dealer, because, and only because, the dealer sometimes supplies the Government also. But to return to the blessed certainty and freedom conferred on neutrals :-

If the cargo is consigned to Brown it is free from condemnation. If it is consigned to Jones it is confiscable, because Jones is known as a person who sometimes supplies food to the Government, If the captain is unable to prove whether it is going to. Brown or to Jones-and this he cannot know-the ship is capturable for adjudication. If, by chance, the captain should be able to show that the consignment is to Brown, a harmless trader, the ship may none the less be captured and may be condemned (as we shall see presently), because the port of destination is, or may be regarded 
as, a base for military forces, and the owners cannot prove tnat the cargo was not destined for such forces. I ask, again, how such confusion as this can make for "certainty," or "unhindered navigation" in the interests of neutral carriers?

And note especially this: that the inevitable uncertainty whether the cargo is or is not consigned to a person who sometimes supplies the Government in itself exposes to capture for adjudication all food supplies to us in neutral ships.

The Novel "Enem "Base" Law.

Now, the law our own Prize Courts have always asserted is this : that the article of foodstufts is subject to condemnation "only if there is proof that its destination is for the naval or inilitary forces of the enemy ....."

These are Sir Edward Grey's own words. The new law fixes the goods with' a presumption of liability "if the place of destination serves as a base for the enemy's armed forces." Now, the Declaration, ignoring the great object of "certainty," attempts no sort of definition of the case in which a port is to be regarded as "serving as a base for the enemy's forces." The new conditions under which cvery port-certainly in England-is in direct railway connexion with one or more of our naval or military bases, receive no notice whatever. It is a simple and undeniable fact of our transport system that a cargo of wheat or flour, landed, ' for example; at Cardiff or Bristol, two peaceful ports, can be railed to Devoinport, Portsmouth, Aldershot, or Chatham in a feu hours. If the enemy's cruisers or commerce destroyers can intercept a neutral ship bound for Cardiff or Bristol, is there any logical reason to prevent them from contending, and contending with reason, let alone plausibility, that these cargoes' n'ere, in fact,' 'destined for a port serving as a base for our armed forces? The Declaration declares it as a legal presumption 'subject to the ow'ners' right of disproof, whatever this might be worth, that foodstuffs consigned to a place serving as a base for armed forces are destined for the use of such forces. It is true that the captor may on adjudication "fail to prove that the port was in fact a base; $O_{i}$ that the owners of the goods may 'eventually, perhaps after the inir is oier, succeed in proving that the forces were not, in fact, the destination of the cargo; but hou' will that help us : hou vill it protect the neutral against liability to capture for adjudication?' If all or any of our ports are liable to be regarded as a base, then any neutral ship carrying food to any of our ports may lawfully be captured or destroyed; though long afterwards the owners of the property may be able to prove that an unfortunate mistake has been committed: Sir Edward Grey says that this is not his view. Unfortunately any enemy if ours will act on his own liberal view of the Declaration; not necessarily on that of anybody else, however individually dis- 
tinguished. Sir Edward points out further that it seems to be overlooked that foodstuffs consigned to a place actually serving as a base are already liable to condemnation, so that there is really nothing in the new provision except that it transfers the onus of proof from the captor to the owners. Also that it will lie on the captors first of all to prove that the port was at the time actually being used as a base. What the Declaration says is that foodstuffs (and other conditional contraband) are presumed to be destined for military uses if consigned to a place "serving as a base." I submit that "serving as" may be plausibly argued to mcan either "which is actually being used as" or "which is capable of being used as." But in any case, how, in the heat of conflict, can a naval ofticer know whether a given railuay port is being actually used as a base or not? Is he going to split hairs about it, do you think? If in doubt, will he not arrest the ship and chance it? . Under the present

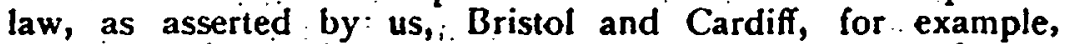
are ports of peaceful consumption to which, in time of war, wheat and flour in neutral : vessels are entitled to free access. Under the Declaration, neutrals will have no right to complain if their ships and cargoes bound to these ports are seized on the ground that the ports are believed, or asserted to be, bases for military centres. And the same with any and every other port. - I ask you, ought we to be content to take our chance of all this in the pleasing confidence : that our enemy and the Prize Courts will interpret the indefinite wording of the Declaration in its most restricted sense? Don't you think. it just as likcly that our enemy and the Prize Courts may aftirm that, in giving it a wider interpretation, they are only applying to it the meaning deliberately placed upon it by the public opinion of our; own great trading centres?

I think.I have said enougis to leave you with no doubt at ail that, whatever the intentions of its individual framers, the Declaration will, as it stands, fully justify the enemy in cutting off any neutral vessels carrying food supplies to this country, whatever the port, even though a final Court of Appeal may decide in certain cases that he must pay compensation. Before passing on, let me remind you that, besides creating certainty, one of the -objects of the Conference was to remove causes of friction. How far do you think the splendid uncertainties of this clause are likely to promote that object?

Just another point in connexion with this clause. Hitherto we have held that it was the right of a belligerent to confiscate foodstuffs actually destined for the enemy's forces, notwithstanding that the goods were to be landed at a neutral port. This, under the Declaration, we give up. If we board a neutral vessel full of flour with every sack of it marked with the address of a Continental enemy fortress, we must release it if the discharge is to be made, say, at Rotterdam or Antwerp. Seeing : that under the Declaration (as I maintain) a 
neutral cargo of flour bound for Bristol can be seized on the possibility that it may be destined for Devonport, our own abandonment of this ancient rule of war seems all the more remarkable. I do not contend that practically the abandonment is of great importance, but on paper, at any rate, the contrast is too remarkable to be passed unnoticed.

\section{The Official Sophistications.}

Those responsible to Great Britain for the framing of this momentous instrument laud it to the skies. They can see in it nothing but good and blessing. They are the theorists. Those who regard it with consternation do so because they see in it a serious danger for their country. They are the practical men. The controversy is essentially one between theorists-theorists and jurists-with no practical knowledge of commerce, on the one side; and men steeped in a practical knowledge of trade in all its workings, on the other. It is well to remember this.

As I have already mentioned, the great Chambers of Commerce of this country have received the Declaration with a chorus of repudiation. The official replies to all such protests have been, in effect, that the dissentients don't know what they are talking about : that they are under an entire misapprehension. Foodstuffs, says Sir Edward Grey, have always been liable to be treated as contraband if destined to the enemy's forces, and if they were, in fact, destined to a Government contractor or to a port from which it might be presumed that they would pass to military uses, they would be capturable, Declaration or no Declaration. There has been much ingenious use of official language to demonstrate this; much sophistry; but it is entirely unconvincing. The word "capture" has, of course, a double signification. It may mean "condemnation by a Prize Court" or merely "capture with a view to adjudication by a Prize Court." This ambiguity has been taken full advantage of by the official apologists for the Declaration. It is obvious that an enemy whom the captain of a neutral food ship may fail to satisfy has the right to capture her, or certainly will assert the right to capture her, for adjudication.' The apologists argue as if the Chambers of Commerce, in representing that neutral food supplies will be exposed to extended risks of capture, were referring only to condemnation after capture, and not also to capture in the hopes of condemnation. Their-the apologists' -argument is, in effect, as follows:- "You say that the Declaration exposes to capture foodstuffs which hitherto have been exempt. This shows that you are under a misapprehension. No foodstuffs can be condemned under the Declaration which have hitherto been exempt."

I don't for a moment agree - with that, but there can, I submit, be no question that food can now be captured for adjudication which hitherto, according to the British view; has been. exempt. All foodstuffs genuinely going to peaceful ports for 
consumption by the populace have been exempt from capture for adjudication. They are all now, I maintain, to be exposed to capture for adjudication, and-oxing to the owner's inability to prove a negative-with, for many of them, an excellent chance that they will be condemned. It is difficult to avoid the reflection that if the apologists had been free to use their quite remarkable ability in exposing the Declaration instead of defending it, we should not be here to-day.

What I confidently affirm is that the whole of our neutsalborne food supplies will, under the Declaration, be in practice exposed to the risk of capture for adjudication, or of destruction in anticipation of adjudication. The London Chaniber of Commerce made this a central point of their complaint; but all the satisfaction they got was a polite reference to the official replies already given. But these replies, so farr as they refer to the point at all, involve it in such a complexity of words that it is by no means clear that they do not refer entirely, as they certainly do essentially, to capture in its sense of condemnation. At any rate, if they were intended to deny the proposition now in question, they are entirely unconvincing, and I fail to see how any denial of it can be otherwise.

It is, as ne know; a penal offence to break open and rob an offertory box. A law is proposed, let us say, under which anybody found in church with money, in his pocket may be arrested and his money impounded until he can prove that it was not taken out of a box which has been broken open. The seat-holders protest. "You are under an entire misapprehension," reply those who proposed the law. "The penalty for robbing offertory boxes will be just the same as it always has been. It will always be opeñ to the persons arrested to show where their money came from; and on their giving satisfactory proofs it will be returned to them. It is melancholy to find responsible persons protesting against a beneficent law which it is evident they have not understood." The parallel is, of course, only to illustrate the sophistry of the official reply to the Chambers of Commerce. My ingenuity is not equal to supposing a case in which the money can be destroyed pending production of evidence as to its source, and of heavy costs to those found in possession of it without being able to produce such evidence when arrested.

\section{A Coping-Stone: The Destruction of Neutral Prizes.}

This all-important new departure demands detailed treatment, but limited as re are to time, 1 can only deal with it very briefly. Till now, Great Britain has always stood out that no belligerent has the right to destroy a neutral vessel carrying contraband. We have now given way on this, as I will presently explain. But first I want to call your attention to this : As the result of our long and costly struggles for maritime 
supremacy, we are the possessors of coaling ports all over the world. This gives us a great advantage over other maritime States, but we bought it at a heavy cost. In the interests of uniformity the Declaration is going, in an important degree, to redress this inequality.: Till now, the law asserted by us has been that a captor must take his prizes into one of his own ports for adjudication. As, amongst the nations, only we have ports everywhere, this would mean that to our enemy a prize would be a white elephant. Before he could get it into port we should have at least a prospect of recapturing it. We have now agreed that if the facts are against his getting the prize into a port of his own, the captor may, subject to certain restrictions, destroy it. We, having many ports, shall not have our enemy's excuses for destroying neutral shipping carrying food or other contraband. Our enemy will be able to sink neutral vessels carrying food to us in as rapid succession as he can discover them, because of his want of ports to take them to. The tremendous advantage of numeious oversea ports secured by us at such a cost is thus minimised in the desire for "uniformity." What would our forefathers say! As to the monstrous proposition that anyone has the right to sanction the wanton destruction of that daily bread for which we are all of us taught to lift our hearts in prayer, it is useless to speak of it. To say that it is enemy's bread is no answer, for the destruction of any bread affects the hungry everywhere.

But now as to the restrictions limiting the exercise of the belligerent right of destruction. Our Delegates, in admitting the principle, congratulate themselves that the restrictions will practically render the right inoperative. But will they? This is open to the gravest doubt: For our enemy will, of course, know that, importing as we do four loaves out of five, any interference with our food supplies may have far-reaching consequences, and this knowledge he will put to the utmost use. Possibly in certain cases in which he may fail to justify the destruction to the satisfaction of the Supreme Appeal Court, probably after the war is over, he may have to compensate $t$ ': $p$ neutral owners. But will such a possibility outweigh the temptations of a strategic policy at any cost to deal his adversary a deadly blow in the matter of his vitally important and absolutely indispensable food supplies? Two of our Delegates were distinguished naval officers. Is this really their professional opinion? Am I, at any rate, not- justified in saying that the knowledge of this further danger to our food supplies will be an added cause for the food panic which it should be our most anxious care to guard against?

\section{The Official Justification.}

Our Delegates were, of coirse, quite alive to the fact that in consenting to destruction of neutral vessels carrying food 
or other contraband, they kere sacrificing a principle on which we have till now invariably insisted. The oflicial argument or explanation is that, while this has been the British view, certain other States have not assented to it, and notably Russia in her recent war. ' Therefore, it is urged, it is better to abandon our contention, and, instead, impose such restrictions on the right of destruction as will reduce its exercise to a minimum. But the abandonment of the principle will have far-reaching consequences. For what till now has been one of the strongest inducements to a maritime belligerent to respect neutral rights? The fact that those rights existed and that to violate them might involve the hostility of powerful neutrals. Under this new law the neutrals will all have signed their rights away. If their property be destroyed this will be in virtuc of a Declaration which they have signed. If the facts should give them any right of protest at all, their remedy will be an application, in case of need, to the International Court of Appeal most probably after the war is over. The deliberate and systematic destroyer of neutral vessels laden with foodstuffs will no longer have to fear the anger of powerful neutrals as a wholesome restraining influence. The Royal Commission on Food Supplies laid stress on the importance of the neutral protest as an effective influence in favour of our food supplies in neutral vessels. The Declaration removes this stumbling block to belligerent food-destroyers in the future. It stood in the way of uniformity.

The EFrect on our NeUtral Supplies.

$U p$ to this point we have been considering the Declaration cinly in its primary effects: the right which it confers upon the enemy to intercept and destroy our food supplies in neutral vessels. There is, however, another aspect, little if at all less serious. For there is an indirect consequence of these new laws; a consequence which at the same time will be advantageous to our enemy and highly prejudicial to ourselves. This conse-quence will be that neutral shippers of food supplies will refuse to send supplies at all to this country, seeing that they will be exposed to such grievous and uncertain risks, and will, instead, direct their ships to neutral ports, and so escape the risks. The result will be that food supplies on which, without the Declaration, we could have counted, will be sent, free of all risks, not to us but to the neutral supply-ports of our enemy, to Rotterdam and Antwerp. How, for example, can it be supposed that, in the case of conflict between Great Britain and a Continental Power, America, with the opportunity of safe neutral destinations, nould send to us food supplies liable to capture, in any case, and probably to condemnation, and with a further liability to destruction: liabilities to which only under this new Declaration will she for the first time be exposed?

"There is no doubt," wrote Lord Lansdowne to the London Chamber of Commerce on 2nd November, 1904, 
"that the uncertainty which prevails as to the interpretation by the Russian authorities of their declaration as to contraband has rendered shipowners unwilling to engage in the carrying trade of Japan, and that many leading firms of British shipowners have refused to accept cargo for Japan."

Just so. It is quite refreshing, at last, to find myself with official sanction for my views!

I have heard it urged that we do not get much food in foreign ships. How much we get, I do not know, but probably 2 good deal more than we could dispense with at a time of panic, or when there was fear of panic. But in time of war the price of food will be so high in this country that a suction will be created which would draw large supplies to us in neutral vessels. Under the existing law, corn could be so brought, at any rate-or so we have hitherto maintained-to our ports of peaceful consumption; and free of heavy war-risk premiums. The Declaration, in the interests of uniformity, is going to stop all this. Neutrals must carry their food to Rotterdam, Antwerp or other neutral port convenient for our enemy, or take upon themselves the risk of capture for adjudication, or of destruction in anticipation of a Prize Court judgment by our enemy.

But there is an answer (of sorts) to everything, and I have heard apologists for the Declaration retort that, after all, we too can get our food from Rotterdam and Antwerp. No doubt, as a general proposition, if one's well runs dry, it is open to us to take our chance of fetching and carrying from a distant pump -if nobody hustles us on the way. But is this a reason for agreeing to a scheme which will make us short of water? We shall, however, not only want food, we shall want it at the lowest possible price. And how much a quarter more will wheat cost us, even if we succeed in getting it, in such conditions?

If the official replies and explanations are unconvincing, they leave at any rate no doubt on this : that the Code is a maze of subtleties and refinements, of uncertainties and dangerous ambiguities. And this when certainty was a special aim?

The Chambers of Commerce have for the most part raised broad practical issues. And just such issues, and they only, can a naval officer, in presence of the enemy, keep before him. No theorist or prize law jurist will be at his elbow, and there will be no hair-splitting under warlike pressure. A doubt or uncertainty he will promptly solve in what he deems the interest of his country: if the law is obscure, so much the worse for the law and the better for him. Where ambiguity exists, he will interpret it his own way, and in so doing he will be far more likely to adopt the practical conclusions of the Chambers of Commerce than the nicely balanoed view's of theorists or jurists; especially if these latter should stand in his way. Let us never forget what others, I think, have forgotten: that, when war 
comes, the practical interpretation of the Declaration will rest with the naval officers of our enemy, bent on injuring us to the utmost. And a law which, by its very obscurities, will promote this object, stands self-condemned.

I regret that I have had to leave without comment points which should not be overlooked: I am well aware that I have done so; but I have already taken too much of your time. What I have endeavoured in my remarks to show: to all who are willing to give impartial study to the Declaration on its merits I believe I shall have shown; is that the Declaration, in its effect on our food supplies in time of war, will be farreaching and most calamitous. In this conclusion I have to support me the deliberately expressed opinions of the Chambers of Commerce of London, Liverpool, and Glasgow, and I do not know how many more. To all such adverse critics Sir Edward Grey replies that they evidently have failed to understand the Declaration. He agrees, apparently, with his Delegates that the Declaration "will be found to be not merely satisfactory from the British point of view, but to constitute an effective safeguard of the best interests of neutrals in general."

It is for you to make up your minds which view to take : and I think you will have no difficuley in doing so. But whether in this $I$ am right or not, I feel assured that you will at any, rate share my unlimited amazement, that whereas not the smallest change can be made in the domestic affairs of this nation except by the will of the people expressed in Parliament, the rights and the very safety of the country and of the Empire for all time can apparently, without any consultation with the nation, be jeopardised at any. moment at the option of a temporary. Cabinet or, indeed; of individual Ministers, stirred by a belief in the virtues of "uniformity"l

Mr. T. Gibson Bowles:-The meeting, I think, is to be congratulated on the extremely able address that Mr. Owen has been so kind as to give us on perhaps one of the most important parts of a subject which began four year's ago at the Hague, which has been continued, through a disastrous series-as 1 think-of surrenders, and which has culminated in the Dcclaration of London in à proposal for an International Court composed of fourteen foreigners and one Englishman, to which Court shall be submitted the judgments of our Prize Courts, the acts of our Navy and of our naval officers, and the judgments even of His Majesty the King in Council which decide the law for the various races of the Britisti. Empire. The importance of this subject cannot be over-estimated; the complexity of it is scarcely to be described. In order really to understand it one has to wade through a thousand pages of Blue Book, about one-half of which is in the French language, and therefore unfamiliar to a great many of us. And the end of it is yet to come. When we ask questioni of the Foreign Office, we are told in a cavalier spirit that we do not understand what we are talking about, and that none but a Forign Offico 
Clerk is competent to juggle with the laws of nations. I wish to make two reservations with regard to Mr. Douglas Owen's Paper. I do not think myself that the new conditions of seafaring and of commercial life have in the least impaired the superiority of the British Navy, provided we recognise those conditions and act upon them. The introduction of steam has not rendered us less but more powerful in comparison with the times when we used sail alone. Then again as to panic. I observe that my friend $\mathrm{Mr}$. Owen says he is not afraid of an actual shortage of wheat-

Mr. Douglas Owen : Not so much.

Mr. Gibson Bowles: Surely if there is to be no actual shortage there cannot be any material increase in price.

Mr. Douglts OWEN : Yes, there can.

Mr. Gibson Bowles: I cannot see that. If you get as much wheat as you had before I for one am not going to pay any more for it, and 1 do not see how you are going to pay any more for it.

Mr. Douglas Owen : IVhat I stated was that the Royal Commission on Food Supply said we should have six and a half weeks' supply at the commencement of the war, but my contention, and the contention of many corn trade experts, is that there would be such a panic created that the whole of that six and a half weeks' supply would be taken into stock at once and the market would be swept bare. The mere fact would cause $\ddot{a}$ rapid increase of price, which itself induces to panic and would itself ensure shortagé.

Mr. Gibson Bowles : Broadly speaking, undoubtedly if our supplies are not interfered with-and the Commission was most decidedly of opinion that there would be no material interference with our corn supplies-the price may rise for the moment, but it cannot be kept up. Mr. Owen is not afraid of shortage, but he is afraid of panic. I really do think that if at the beginning of a war we are to give way to panic, we had better give up all idea of waging war altogether and submit to anybody who chooses to impose conditions upon us. We cannot regard the old romen of either sex or of either service. When it comes to a fight, you have to put the panic-stricken people down below and you cannot legislate for them or take account of them.

\section{Mr. Douglas Owen : Half the nation?}

Mr. Ginson Bowles: I do not at all agree to that. Not half; no, nór a tenth of the nation. I merely make those two remarks, Sir; otherwise I am in entire ágrement with the paper Mr. Owen has read, and I think he has not insisted upon all the new disadvantages that would be imposed upon us, not merely by the Declaration of London, but infinitely more by the establishment at the Hague of an alien Prize Court, to judge not merely the Declaration but every English naval officer and every proceeding of the Navy. That is the real danger. Let me enumerate, if I may, very shortly, the new disadvantages to which we should be exposing our food supply. Perhaps, Sir, even in your presence I may go so far as to make an apotheg'm of Naval War: The object of Naval War is to keep all our trade always going and to stop all the trade of the onemy-to cut his communications and to keep ours always open. Thit is the end of naval war. You may do it by destroying his fleets or bottling them up-it matters not so long as you cari keep your communi- 
cations open and stop all those of the enemy. So long as your trade is kept going and his is not, you are certain so to distress him that in a short time he must sue for peace. In connection with commerce in time of war, let us see the new things that this Declaration would do. In the first place, what is to be contraband and what is not is no longer left as it always was left to the judgments of the Courts, considering all the circumstances of the case. It is now put into hard and fast lists. We are told that that will make us more certain as to what contraband is and what it is not. I say No, for these lists may be added to at any moment by a belligerent, excepting of course the list of free goods. The list of contraband and of conditional contraband may at any moment, for his own convenience, be added to by a belligerent by mere declaration, so that a vessel which has sailed from a distant part of the earth when she comes near the belligerents' shores may suddenly find that the cargo with which she started as a free cargo has, during the course of the voyage, become contraband and liable to seizure. Then there is the question, very ably treated by Mr. Owen, of the .base of supply. We have only to look at the map of Europe to see how short a distance our ports are from our naval arsenals. Bristol is equally good as a base for Portsmouth, Plymouth, or Chatham. That is not so with the larger Continental. States, with their fewer and more distant ports as bases of supply. Whenever it comes to a question of the doctrine of the base of supply, as applied to a port and its distance from naval and military forces, we are at a special disadvantage as compared with every other large nation of the Continent. Then I come to the most outrageous and impossible doctrine, that a cruiser capturing a neutral suspected of carrying contraband may out-of-hand burn or sink her. There is no parallel to that that 1 know of likely to convey the monstrosity of the thing to the ordinary citizen except to say that every policeman who arrests a man on suspicion of murder may out-of-hand hang him to the nearest lamp-post, without trial or enquiry.

\section{Mr. Douglas OWen : And try him afterwards!}

Mr. Ginson -Bowlens: Yes, and try him afteruards, no doubt.: But observe that in this case the destruction of the neutral ship with her cargo said to be contraband not only destroys the culprit, but also destroys the evidence. Therefore it is the more outrageous. Then not merely is this destruction to be effected by the men-of-war of the enemy, but it is to be effected by. any one of his merchant ships converted into a so-called man-of-war in any part of the world at any moment. I do not know whether my countrymen realise what that means. It means that a country infinitely weaker than. Great Britain in warships, but with a numerous fieet of merchantmen may provide them all with little bits of paper and bunting and a few three-pounder guns, enough to tackle a merchantman, and those ships spread all over the world may, on the . outbreak of war, produce their paper commission, run up their bit of bunting, bring out their three-pounders, and announce themselves as men-of-war, competent not only to capture but to sink any British merchant.man that she may come across, and also any neutral merchantman that she comes in contact with. Under. the old law that was piracy. It is piracy now. It is piracy under a new guise, and it is a revival of privateer-. ing in the most insidious and dangerous form. Yet that has been agreed to at the Hague. It is not forbidden by the Declaration of London. 
Surely this audience cannot be surprised if some of us feel most indignant as well as most alarmed at what has been done. Now, Sir, all these alterations with regard to neutral trade are against Great Britain, and they are all in favour of her enemy. Mr. Douglas Owen, the able lecturer has already pointed out how in respect of ports for adjudication it works against us. We have ports all over the uorld to which we can take any capture and submit it to the Prize Court there, as is the only proper way. Our enemy has probably scarcely any ports of the kind, and consequently he will nevcr think of taking his captures in for adjudication. What he will do, and what he will be supported in doing by the Dxclaration of London, will be to:burn them, to sink them, and to dispose as he can of their crex's. Now I come, for a moment, if I am not trespassing on your time-and really it is a little difficult to dispose in ten minutes of four years' work and a thousand pages of Blue Book.-

The Chairman : As in the House of Commons and the House of Lords, he Chairman is entitled by the rules to extend the number of minutes given to each speaker.

Mr. Gibson Bowles: I have had the misfortune. to cease to be a member of the House of Commons, which I mainly regret on account of this very Declaration of London. But far more important than the maintenance of our own trade and our own food supply to these islands in the time of war is the effect of the Declaration and the Prize Court upon our offensive power at sea. When $1 \mathrm{am}$ at war it is of course important to me not to be starved or half-starved, but if I am at war. I would rather be half-starved than lose the war. That involves everything. That involves not merely my prosperity, but my very existence and the existence of the British Empire. Therefore I say that transcending in importance the subject that has been treated to-day as a part of the Declaration of London is the influence of the Declaration itself upon our offensive power when at uar. Take blockading. The Declaration of London practically makes blockading impossible. It makes it all but impossible first of all to establish the blockade, to maintain it in its effective character; it makes it quite impossible to stop the blockade runner, because he has only to stay outside a certain line and wait for his opportunity to get in. It abolishes the powcr of capturing a blockade-runner up to the end of his voyage, and it therefore impairs your power to punish him. I cannot dwell on the details, although 1 have them all present in my mind, but practically I do say-and I undertake to say that any naval officer will agree with me-that this Declaration of London would practically render all but impossible that effectual blockade which since the Declaration of Paris is almost the only effectual weapon of offence left to us. Then 1 conie to the convoy. In the year 1800 , when it was proposed by the Armed Neutrality that a convoy-a torpedo boat, say, in these modern days-should cover a fleet of fify merchantmen, William Pitt put into the mouth of King George I. -

The Cinarman : Are you referring to the convoy of neutrals?

Mr. Girson Bowirs: Yes, Sir, I thank you; I should have made that clearer. When I speak of convoy I mean the new principle established by the Declaration that neutral vessels under the convoy of a man-of-war of their own nationality shall not be liable to search, to visit, to question, or to anything. They may, perhaps, not be neutrals; they may be faloe 
neutrals full of cargoes of contraband; but not a word can a British naval officer or a British naval flect ask one of those vessels, and no examination can be made of their papers, as long as they are under the convoy of a torpedo boat or a torpedo boat destrojer, or even of a submarine. Then take the list of contraband. In the list of free goods, goods which can never be called contraband, are mineral ores. Does this assembly know where all the guns of Essen come from? They start from Spain as metallic ores; they go to Rotterdam as metallic ores; they are then taken to Rheinhausen, where they are made into pig iron, from Rheinhausen they go to Essen, from whence they emerge as arms and ammunition. Not $\dot{a}$ pound of that can you stop on the sea, although it is the most essential of contraband having regard to its destination as I have described.

The Chairman : I think we inust keep to the subject of the destination of our food supplies.

Mr. Grason Bowlas: With that single illustration, Sir, I hope I shall not further transgress. Now to come back to the general effect of this Declaration, food supply and all the rest. What is contraband in the uay of food or of other things? What is a base for supply of the armed forces of the enemy? All these questions will no longer be decided by the ancient tradition of the hionourable Courts of Admiralty putting into force not our municipal law but the law of nations. They will in the end all go at last to a Court of Foreigners sitting at the Hague, fourteen foreigners to one Briton, a Court making the law itself-I am quoting the words-a Court bound by no legal gystem of proof-i am quotin's the words-a Court which comes to its decision with closed doors, and whose decisions always remain secret. That is the Court. which will decide whether Bristol really is a base of supply for Portsmouth, or! whethet any of the other questions relating to food are to be decided for or against us. That to my mind is a greater danger, a more real and effective danger to us than even the Declaration itself. As the food supply hangs on the Declaration, and the Declaration hangs on the Prize Court, so does the Prize Court hang upon that Naval Prize Bill to which the lecturer has alluded. The whole hangs at last upon that Bill. I could speak at length upon the other aspects of this subject, upon the Bill and upon the Court, but I' will say nothing further except that I do earnestly hope this meeting at any rate may have the effect of warning Sir Edward Grey from declaring that those who are opposed to this Declaration and this Prize Court are only so opposed because they do not understand the subject. We have come much nearer to understanding this side of the subject, at any rate, since the able address we have listened to to-day, and I am perfectly certain, whether we are concerned with this side or with other sides of the subject, the more we examine the proposed alterations the more we shall determine that they must be resisted, because they are destructive of the rights and contrary to the interests of the country in which we live.

Commander the Right Hon. Lord Ellinborough, R.N.:-I am very glad that Mr. Douglas Ouen has brought this subject of the Declaration of London before us, and I hope that our Chambers of Conmerce will persevere in their opposition to it. I think that the lecture we have just listened to will be of great assistance in forming public opinion on this matter. I hope our Chambers of Commerce will continue their agitation 
until it is decided that this Treaty shall not be ratified. I would almost as suon hear of a lost battle as of the ratification of this Treaty. It gives away the reșults of many campaigns, both on land and at sea, without granting us any equivalent advantages. If we were at war I think we should be more likely to become embroiled with neutral Powers under this Treaty than we should if matters remained in their present state. The heading of this lecture is: "The Declaration of London and our Food Supplies," and the Chairman has told us that we are to stick to the food supply part of the subject only. Of course, if we were to touch on the Declaration of I.ondon as a whole, it would take far more time than could be given to it, and it certainly could not be adequately discussed in the course of one afternoon. But there is a danger that it' may go forth to the world that the Food Supply Clauses are the only clauses in the Declaration of London that have been objected to. Against that interprctation of it.I for one wish to enter an emphatic protest. When I first saw the heading of the lecture I came prepared to attack a great number of the clauses, but of course that part of the matter is now struck out, though I hope to find some other occasion for saying what I think about them. I am in thorough agreement with the lecturer when he lays down that when we are neutrals, our risks in war are only pecuniary risks, and that they only affect a very limited class, a comparatively small proportion of the population; : but that when we are at war ourselves, our risks will be those of every man and woman in the country, whose very existence as a nation will be at stake. Now think how small were our losses as neutrals in the Russo-Japanese War compared with what they would liave been had we been belligerents; even if successful. The possession of a powerful fleet, good diplomacy, and commonisense, brought us safely: through that critical period. Mr. 'Owen has, I think, proved his case when he says that the Declaration leaves the whole of our neutratborrie food supplies exposed to capture or to destruction, and that the ment and grain, on the receipt of which we might have reckoned, would be diverted and sent free from all risks to Rotterdam or Antwerp. instead of going to Liverpool or Glasgon:. Until Mr. Owen told us I did not know that three-fourths of Germany's overseas corn comes through Rotterdam and Antwerp. It is a fact well worth remembering." By far the greater part of our own food -supply is brought to us by British ships, but that is no reason why we should deliberately; by our own act, cut of any other'source of ' food supply. It is better. to have tu'o istrings to your bow than one. I have read the Blue Book on the subject of our food supplies-a very large book, full of information, which takes a great deal of time to assimilate and study, and 1 entirely agree with the lecturer in thinking that undèr the present circumstances a panic as regards our food supply is very likely to occur at the commencement of a war, and that any interference with. Neutral-borre food supplies or the possibility of interference with them is very likely to accentuate that panic. The fault of the Treaty from a British point of view is that it appears to have been drawn up by men whose minds were exclusively occupied by thinking of single ship captures only, to the exclusion of stoppage of trade. The real object of the capturing of ships is to stop trade, and success is most complete when no ships are captured at all, when ships are laid up in harbour with their crews and people unemployed, simply because their capture is certain if they attempt to go to sea. By the capture and destruction of the Knight Commander, the Russians gained their object 
for awhile. After that capture no neutral ships laden with railway iron attempted to go to Japan until some time after the Russian squadron had been defeated and driven back. By destroying one ship they postponed the sailing of others, and thereby interfered with the construction of the military. railways of Japan in Manchuria. These questions are not mere

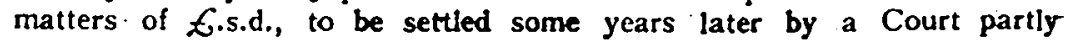
composed of Mulatto judges. The effect of the capture of a ship often has an immediate result. What can tha subsequent decisions of an. International Prize Court matter to a nation that has lost one-half of its numbers by starvation? No decision of this International Prize Court wilf: bring the dead back to life. Belligerent rights are entirely questions of the higher naval strategy and diplomacy. No country would ever allow itself to be ruined for the sake of a clause in a Treaty. It would be most unwise for us at the commencement of war to insist upon every right that belligerents have ever claimed, but all waivers of right to interferewith neutrals should be temporary only, and we should be in a position to re-assert them on other seas if the theatre of war was changed. If we tie ourselves to a hard and fast Treaty we cannot assert any belligerent right when we want it. I may say that I am in favour of asserting every. possible belligerent right on our own coasts and waiving a great many on the distant seas where our interests are not vital. The re-assertion of: belligerent rights, once given up, would be more likely to involve us in an additional war with a neutral than a re-assertion under present circumstances. During war, our Admiralty and our Foreign Office ought to. do their best to conciliate neutrals on all points not vital to our existence. One would have thought that the opinions of naval men would have been: invoked : in support of this Declaration; but I have not yet heard that any Admiral who has commanded the Home, the Channel, or the Atlantic Fleets, has expressed himself in its favour. I have found a number of naval officers who think : that the Declaration of London does not really matter at all because they say it will be torn to pieces and fung into the waste-paper basket when hostilities commence. . Why, then, ratify it at all, and thereby increase our chance of quarrelling with neutrals, if we are to throw it aside when war breaks out? I look upon quarrels with. neutrals as one of the chief things we must avoid when engaged in a life: and death war; but we must leave the hands of our seamen free to. interfere with neutrals when necessary; and we should, not bind them. doun by clauses in an International Treaty. Why not send the Declara-. tion down to Portsmouth and have it discussed by the officers going through their war course studies, and then let us know what theiropinions are? It really appears as if some of our countrymen are determined that our seamen's hands shall be so tied as to make it impossiblefor them to save their country from famine. The Declaration of London. may be treated with respect if a war was to break out between two small, Powers, like Greece and Turkey, because they would do their fighting in. the neighbourhood of superior neutral fieets; but no two first-class Powers would ever allow a sheet of paper to interfere with their prospects of: success in a serious struggle. The supporters of this Declatation consider that it adds an International Prize. Court to existing Prize Courts. On the contrary, the practical effect of Article 49 is to abolish Prize Courts. By it, every officer in command of an armed ship becomes a Court in. himself; he is a Court of first instance with power to burn, sink, or: destroy any neutral ship carrying food to Fngland--and by so doing, as. 
Mr. Bowles pointed out, destroy the evidence which would otherwise have been placed before a Prize Court. Small ships cannot make captures; it is simply impossible. There is not a small ship at sea whose commander could not say: "It interferes with my duty to send twenty or fifty men on board that ship to navigate her, and therefore I can do nothing but destroy her." "The lecturer was right when he told us that the practical interpretation of the Declaration will rest with the naval officers of our enemy. Yet British naval officers will not have similar powers over neutral ships carrying food to a port on the Continent because the food would be disembarked in neutral territory within easy reach of the enemy's frontier. It is a one-sided Treaty. We live on an island, and we are now making laws to prevent the importation of food to this country and giving free importation of food to Continental Powers in time of war! The victorious belligerent, whose success might perhaps be due to his having disregarded the Declaration of London, might put a clause in the Treaty of Peace making the vanquished nation liable to all the pecuniary damages that may have to be paid by the successful country in consequence of the decisions of the International Prize Court. He knows that it would not affect him, as he is going to win; and because he has not got to pay damages he will destroy what he likes. Another point that appears to have been forgotten is that at the conclusion of the war one of the belligerents may have become bankrupt or refuse to pay. When the American Civil War came to an end, the Re-United States claimed all the property that was in the hands of neutrals that had ever belonged to the Southern States, and they refused to pay any of the liabilities of the Confederacy; so that you would have got nothing out of Southerners who captured your ships if they had captured any neutrals in that war: Then Article on declares that the Treaty cannot be denounced until twelve years have clapsed. By that time new inventions will in all probability. have completely altered the strategy and tactics of the sea. This Treaty is out-of-date and retrograde now, but what will it be in twelve years' time? Surface men-of-war may have disappeared from the occan and their places taken by mechanical inventions, which as yet no man can foresee. One year's denunciation ought to be sufficient. As Mr. Bowles has pointed out, by not mentioning the subject, the Treaty gives tacit permission to convert merchant ships into men-of-war when on the high seas, and vice versa. If an enemy's ship is to be allowed to capture and destroy merchant ships at sea, enter a neutral harbour under a merchant ship's flag, coal and re-provision, and then go to sea again and hoist the fiag of a man-of-war, and capture neutrals again, what is she to be called? Privateering is said to have been abolished, but what is a volunteer fleet but a privateering fleet under another name? Any light obsolete gun can stop or sink an unarmed merchant ship. All that such ships require is speed, and an officer holding a temporary commission. That officer need never have served in a man-of-war, and he may be a native of a neutral country. Yet that man is to stand on the bridge and settle whether neutral ships belonging to other neutrals are to be burned or sunk. Formerly, privateers had to send their prizes in for adjudication, but the privateer of the future will be his own Prize Court. In conclusion, I will repeat that I hope the Chambers of Commerce, Mr. Burgoyne, and Mr. Bowles, will continue the agitation against this Declaration.

Admiral the Hon. Sir E. R. Frenantez, G.C.B., C.M.G. (Rear-Admiral of the United Kingdom):-I think the ground has been so well covered VOL. LV. 
by the speakers this afternoon, especially by Mr. Gibson Bowles, who has so thoroughly mastered the subject, that there is not very much left for me to say; especially as I did not intend to deal principally with the food supply but rather with the other aspects of the question, which are at least as important in my opinion as those which have been touched upon this afternoon. I will only just allude to them-deferring to your decision, Sir-with reference to the question we are discussing at this moment. Perhaps I am a bit of a Philistine, buit I venture to say that I do differ on the subject of the intention with which our Government has acted with regard to the Declaration of London. I am of opinion that the less we interfere with what is acknowledged, or has hitherto been acknowledged, by custom to be the rules of International Maritime Law, the better. It cannot have escaped the observation of all those who have studied this question that every new war has made some change in what had been previously generally understood as International Law. I should only just like to mention as an example that there are two countries which have been pre-eminent up to the middle of the last century as the greatest opponents of belligerent rights and the greatest supporters of the rights of neutrals; those two Powers are the United States and Russia. Now we know that in the American Civil War the United States strained their belligerent rights to a very great extent. They extended the ideas of blockade as they had never been extended before, and as we had never attempted to carry them out in our war with France. 1 believe they declared a blockade of 2,500 miles of coast with seven ships originally, and that was directly against what had been a cardinal point of the Declaration of Paris. When ae turn to Russia we find that Russia has always supported the rights of neutrals, and yet we saw that Russia in the late war strained her rights-if you may call them rights-by doing what we never did in our great war when we wero fighting for our existence-to destroy neutral vessels. It does seem to me that to acknowledge those so-called "belligerent rights," those strained belligerent rights, was undoubtedly a mistake. We should have stuck to our old ideas and said: "We have never allowed this before, and we do not allow it now." The same thing holds good with regard to the importation of food stuffs. We have always protested against making food stuffs contraband. It is true that on certain occasions-and circumstances do alter cases-when food stuffs were really consigned for the benefit of the enemy's armed forces; we have declared them contraband; but we have always protested energetically against their being declared generally contraband under any circumstances. The case of the Freacti in China in $188 \mathrm{~g}$ is one in point. The French declared rice contraband. That rice was what was called in China "tribute rice"; it was not simply food for the people but money for the Government, and therefore they had something of a case in declaring it contraband. But we protested in the most energetic manner. It is trie that Germiany, I believe, acquiesced at that time, but Germany may have had its own reasons for acquiescing. We as the greatest maritime Power, with the greatest experience on these subjects, strongly and energetically protested. It is true :also that in 1794 we did stop, or tried to stop, a large cargo coming across for France from America; chiefly in American ships, but we did not propose to sink those ships or even to capture those ships permanently; we proposed to capture them temporarily; bring them into our ports, pay for the food 'stufis, and afterwards release the ships." If that proves anything surely 
it proves that though under the stress of war we may have been willing to allow that under certain circumstances we were. justified in interfering with food supplies, we did so with every consideration, practically acknowledging the fact that, as a rule, food stufis must be considered immune from capture. In Sir Edward Grey's instructions on Ist December, 1908, he said that certain things were to be considered. I will not read them all, but there were questions like the rules of transfer of merchant vessels from a belligerent to a neutral flag, the doctrine of continuous voyage, and the question of domicile, I admit that those three comparatively. subsidiary questions were such as might very properly. be considered in peace-time, and that all countries would have a similar interest in dealing with them; but when we come to the other questions; such as contraband, blockade, destruction of neutral vessels, the legality of the conversion of a merchant vessel into a was ship on the high seas, I venture to think those were not questions that we ought to have considercd at all; and that when Sir Edward Grey speaks, as he does, of " the proposals of Ilis Majesty's Government having met with a gratifying reception," it was because, evidently, we were prepared more or léss to waive those subjects on which we ought to have protested, and have refused to go on with the Convention which dealt with them. I should just like for one moment to refer to the Declaration of Paris.

\section{The Chrirman :-Is that connected with the subject of food supply?}

Admiral Sir E. R. FremantLe :-No, it is not directly. I was going to say that $I$ did not wish to speak against the Declaration of Paris, but that $m y$ contention is that we were dealing there with a fact which was quite obvious to everybody, a broad principle which was easily understood, and that we thought we had been given a counterpoise on the question of privateering. I entirely agree with $\mathrm{Mr}$. Gibson Bowles that allowing merchant ships to become men-of-war at their pleasure on the high seas is privateering in its most virulent form and very much worse than the privateering that was allowed before. If this Declaration of London is ratified, we have waived our maritime rights to a very great extent. I have been reading lately, as many of us have, I have no doubt, Mr. Julian Corbett's recent book on the "Campaign of Trafalgar," and it is very remarkable to see how determined Mr. Pitt was in 1805; notwithstanding that he was desirous above all other things to secure the co-operation of Russia, which was so important to him, not to waive in the slightest degree our belligerent maritime rights. It is very important, whether connected with the food supply or anything else, not to forget the warning which Admiral Mahan gave us when he said that, Germany and the great central Powers of Europe, being so strong on land as they are, the only counterpoise is the belligerent rights and the great maritime power of the British Navy. I certainly do not agree with the International Prizo Court. I cannot believe that we shall have justice or fairness from that Prize Court. I cannot understand how rules, can be adopted that are equally fair to an island Power and to a Continental Power. Sir Edward Grey has agreed not to ratify this Declaration without the consent of Parliament; he has admitted that we shall have a discussion upon it, and it is fortunately necessary before the Declaration can be ratified that Parliament should pass the Naval Prize Bill. Let me just call attention to one point of the very highest importance-a point that I had. the pleasure of bringing to the notice of the British Empire Lcague. We are 
an Empire with Colonies. Surcly those great Colonies of our Empire, cur Great Britains beyond the seas, with their large mercantile marine, ought to be consulted in this question of maritime rights, which touches them very closely. I was looking up the subject the other day and I found that taking Australia and New Zealand only, they come fourth on the list of the mercantile navies of the world. They come before Italy, before Spain, and before Russia, and they come before most countries; and next after France. Under those circumstances $I$ do think it is extraordinary levity, to say the very least of it, to propose to ratify a Declaration which all these Chambers of Commerce that have gone closely into the question declare is dangerous to our national interests. There is just one word more I would like to say. I have taken the trouble to read a great deal of the correspondence-I cannot say I have made 2 study of it, as my friend Mr. Gibson Bowles has done-and I find there is one triumphant answer which apparently Sir Edward Grey thinks he makes. He says the shipowners of Liverpool approved of the Declaration. Their principal reason for approving it is very remarkable; they approve of it because they say: " $A \mathrm{~h}$, I see now they will be able to destroy neutral ships bringing us our grain; that is most important to us, because we shall not be able to trust the neutrals, and we shall be bound to have nur own ships thoroughly protected; and it is more important to us as shippers that our ships should be properly protected than that the country should receive a certain amount of food stuffs in foreign ships." If that is the best that can be said for the Declaration of London, I entirely agree with the lecturer, who has placed the position as regards the supply of food stufis so clearly before us, and I think it would be a great advantage if we consld have another discussion on the Declaration, in which we should be able to deal with all those questions which Lord Ellenborough and others have been so anxious to deal with.

Major S. L. Norris, late R.E. :-I am almost ashamed to starid up here because I have now hardly anything to say. I did mean to speal for about two minutes, but the two eminent naval officers who have spoken have mentioned what I thought was the one omission in the valuable address that I read very carefully before I came, the question of privateering. There is one point and one only I should like to mention which does not seem to me to have been brought forward, and one which affects the question of the ratification or not of the Declaration of London. The next war in which we are concerned will not be run on red tape, and I very much doubt whether the old women of the Navy, and the old women of the Army will think very much of sophistications about this, that and the other when they have the country to keep from starving. Therefore I think we should protest against tying their hands beforehand with a whoie lot of arguments. I am sorry that I have nothing else to say

Mr. Harold F. IVyatt :-It might be of some possible interest tc' the audience to know the names of certain other Chambers of Commerce protesting against the Declaration, besides those of London, Liverpool, and Glasgow mentioned by the lecturer. They have all passed resolutions of protest against the ratification of the Declaration, and I have their resolutions in a pamphlet I hold in my hand, issued by the Imperial Maritime League. Amongst the Chambers which so protested and passed resolutions are, besides London, Liverpool and Glasgow, Leith, Edinburgh, Belfast, Nottingham, Newcastle, and Bristol. That list is only complete 
up to a little while ago, and the number has been constantly added to. The Imperial Maritime League are communicating with all the Chambers of Commerce throughout the country and throughout the Empire, because the oversea dominions are also deeply involved in this matter, 2sking them to pass resolations of protest, and I think it is more than probable that a very large number of them will do so. Wo are to be congratulated this afternoon on having been allowed to listen to a paper which we shall all admit is one of the ablest that could have been written on this subject. We have also had the great advantage of bearing the comments of Mr. Bowles, than whom no greater authority on this subject exists. But there is a point of divergence between the lecturer and Mr. Bowles which appears to me to be one of extreme importance; it is as to the effect on prices that will be produced by captures made at sea. An ounce of fact is worth a pound of theory; as is often said, and I venture to allege this fact in support of the lecturer on that point. In the year 1898, when war broke out between the United States and Spain, there was a rumour, quite unsubstantiated, as it proved, of a possible interference by Spanish cruisers with United States ships bringing food to us, and the effect of that rumour, before a shot was fired to materialise it, was to send up the price of wheat on the exchanges of England from $28 \mathrm{~s}$. to $37 \mathrm{~s}$. a quarter, which was equal to the imposition of a 95 . tax. The effect of that again was to increase the price of the ordinary loaf to the extent of about a farthing to a halfpenny. If that was the result of a mere rumour of a possible interference which never took place, in a war in which we were not engaged, what is likely to be the effect of the outbreak of a war in which we ane engaged with a :great naval Power, and of the sudden realisation by the British public that we had scarcely any British cruisers on the seas of the world to defend our trade? I should say everybody would agree that the effect would be all that the lecturer forecasts, and that we should have an enormous panic in this country and an immense rise in the price of food. The brevity or length of such a panic is certainly a matter for consideration, but I am afraid the effect which it would produce would not need necessarily to be prolonged. A week's panic or a fortnight's. panic would be enough to bring us to our knees when we had starving mobs rushing through the streets and we had to call out the troops to shoot down crowds of looting people. The situation which would be created would be intolerable. Sir Edward Grey practically admits, I. think, that the effect of Article 34 in the Declaration of London will be to render all food stuffs coming to this country in neutral ships subject to capture. At any rate, I draw that inference from his reply to the Glasgow Chamber of Commerce. The Glasgow Chamber drew attention to that, and Sir Edward Grey or the Foreign Office, writing under date of 13th October last, said that in all these cases it is still open to the owner of the goods to prove that they were not destined for military or naval forces by saying that they were in fact for peaceful purposes. In short, therefore, the effect of Article 34 is only to shift the onus of proof in the cases specified from the capturer on to the owner of the captured goods. That is all it does, and accordingly Sir Edward Grey contemplates quite clearly that such goods coming to England during a war in neutral ships shall be capturable, and his consolation administered to the Glasgow Chamber is that it will be open to owners of the goods to make representations in the proper quarters, which will be the International Naval 
Prize Court if it is ever established-I hope it will not be-and that Court may then, if it thinks fit, grant compensation to the owners of the captured goods. Of what possible avail will that be to starving: England, to the crowds of people, the mobs, who are perishing owing to famine prices? IVhat use is it to tell them: "Do not grieve, good: people; the owners of the goods may reccive compensation by-and-bye"? There never was, I suppose, such an instance of complete inability on the part of a Minister to grasp the vital essence of a subject with which he had to deal. There is one food which is hardly worth mentioning, and one drink, which are cxcmpt from capture; the food stuff is nuts and the drink is hops. Therefore it may be inferred that the diet of England in the next naval war, as designed by the Foreign Office and the present Ministry, is to be a mixed diet of beer and nuts. What this Declaration of London really does, I submit, is to cxpose neutral shipping, bringing us food stuff in war time, and all other conditional contraband, to exactly the same interruption that will be incurred by British merchantmen. What chance have we of receiving food supplies in our own British merchantmen. withouit interruption? That depends on the state of our Navy.: What is the state of our Navy that is actually stationed now on the distant trade routes in order to defend the British people in time of war? I had occasion to go into that point in writing a paper for one of the Reviews last year, and I found that the total number of British cruisers stationed on the trade routes outside the waters of Europe was twenty-seven. The figure which is given by some reliable authorities for the British Mercantile Marine, the total number of sailing ships, stcamers, big craft, and small craft, is thirty-seven thousand; it is said that thirty-seven thousand vessels of all kinds are comprehended in the British Mercantile Marine, including the whole Marine of the Empire. A very large proportion of this thirtyseven thousand, an enormously preponderating proportion, must be certainly outside the waters of Europe, and all that proportion has for its defence is twenty-seven British cruisers plus now the Rainbow, which has been taken over by the Canadian Government.

The Cratrman :-I should like to point out to you that the question is: The food supply in time of war.

Mr. IVyart :-That is the thing, Sir, on which I am trying to. speak,

The Chairman:-You are talking about the distribution of the Navy in the time of peace, last year.

Mr. Wyatr:-I bow to you altogether, but I was trying to illustrate the matter by a point.

The Chairuan:-You must kindly adhere to the subject ne are. discussing : Food supplies in war.

Mr. Wyatr :-Certainly. My reason for mentioning the points I have mentioned was that I thought they had the most vital bearing on the question of our food supply in war. If the naval protection of the British. Empire is inadequate to protect the British Mercantile Marine, and to chase away enemies' cruisers and the enemies' converted merchantmen, and thus protect neutrals as well as our own vessels from capture-if the Navy cannot perform that task, it appears to me that our food supply in war must be hopelessly interrupted and famine prices must prevail in this country. That is the main point I want to bring out. I vasuld only 
say. further that every possible effort is being made by many people, and overy effort is being made by the Imperial Maritime League to draw public attention to this question. The League has called a great meeting, 1 which is to be held on the 2nd of Febriary, at the Baltic Exchange by kind permission of the authorities of the Baltic Exchange, and I invite everyone who is interested in this subject to attend at that meeting. The whole future of England seems really to be involved in this question, and if the people cannot be awakened, if the ratification of the Declaration of London and the passing of the Naval Prize Bill cannot be prevented, it would seem vain to hope:for any future for the British Empirc. But I trust and I believe there still remain forces in this country which will be adequate to the occasion, and that .we shall succeed in dissuading .His Majesty's Government from putting the hand of England to this instrument of national destruction:

Rear-Admiral R. TupprR, C.V.O. :-Other speakers have alluded to the possible panic which may arise on the question of food by the outbreak of war, but there seems to be a difference of opinion as to whether there will be a panic or not. Mr. Gibson Bowles apparently thinks not. But my. contention is, that whether there is likely to be a panic or not, we ought to organise and prepare for it, : as that is the sure way to prevent it spreading if it appears in one or more places. In my humble opinion every lady and gentleman in this room could assist very materially in preparing such an organisation.: We have County Councils, Village Councils, Town Councils, and various Municipalities, all of which are perfectly well arare of the state of wages in their particular districts. Generally speaking, we may say that there are seven million people who are dependent on wages under 23s. a week; there are something like thirteen millions who vary between 235..1 and $\mathscr{C}_{2}$ los.; and something like six million who have more than that. The seven million who are on the lower wage are'the people who must be very hard hit immediately food rises in price; and amongst those seven millions unfortunately there are many, who are not in favour of maintaining an Army and Navy at all, and consider that money spent on its maintenance is wasted; in fact, a man who had recently been a Member of Parliament and controls thirty thousand steel workers, told me it did not matter to any of them, his followers, by whom this country is governed, and they did not want Dreadnoughts or armies, or anything of the soint, and no doubt they would also like to do away with policel That is the class that also will probably be hungry the first. It seems to me therefore that we ought at once to consider and organise a means for immediately meeting the situation if food rises in price. All the Municipalities and Councils should review the situation in their respective districts; should find out how much food there is available, how long it can last at full, half, and one-thirc rations (for it is quite likely it will be. difficult to replenish stocks), aud should organise to conserve that food and detail buildings, in which the food could be stored and guarded, and the force necessary to guard it, - for it will have to be guarded most likely-and should organise the issue to those who most requirc it, possibly by tickcts. If the officers of the various Councils I have mentioned would sit down and think it out now, it is possible that without expending a great deal of money, they might be able to omplete an efficient organisation. If they wait to do it until the eventuality arises, I am quite certain they will not be able to effect 
anything, and panic must then ensue. It is a matter in which $I$ have been very greatly interested, and I have tried hard in my humble way to interest others. : Three Mayors said they would undertake it, but two of them have put it aside altogether, and the other says he is going to do it this year. It seems to me it is quite easy to do. Information about the food can be obtained, also the information about the people who may be in want of it. It seems to me that all that is required is to make out the scheme and put.it in a pigeon-hole; with the cards for distributing to the families who may need to purchase food at ordinary prices, or perhaps even be given it when food becomes dear; and then as the price rises the people will present their cards and obtain food. Such an organisrtion and the knowledge it existed would avoid this panic, and give confidence to all, even though some suffered from insufficient food. If a panic does occur soon after the outbreak of war, and before the Nay is able to prove it can make the sea free and guarantee our food suppty. I fear that naval officers like myself, who hope to be some distance from our shores on that occasion upholding the honour of the Empire, may have our hands tied, by the making of an inglorious armistice just when victory is within our grasp, and it is up to us naval officers to do all we can to impress this danger on our countrymen, and persuade them to think of some organisation which can prevent the possibility of a panic and riots when people are hungry. I would add that it will also be necessary to see that no food is sent out of this country when war becomes imminent. I have heard of an organisation for buying up as much food as can be obtained and shipping it abroad; this undoubtedly must also be guarded against.

Major R. A. Jornson, ith Battalion Hampshire Regiment:-We haveheand a great deal about the evil effects that will ensue if we pass the Deciaration of London. Now, I think a good many thick-headed people like myself are not quite clear in our. own minds as to what are the facts if we do not pass this Declaration. ("You are as you were.") Quite so, but how are we as we are?. So far as I can see-and I have spent some time and trouble over the matter-it appears to me that most of the horrors with which we are threatened; if we do sign the Declaration of London, will threaten us just the same if the Declaration is not passed. That is a question that has not been dealt with by those who attack the Declaration of London, although of course they have'no doubt their view upon the matter. It emphatically requires to be dealt with: For instance, we are told by the Lecturer that if we sign this Declaration our enemy will be able to sink neutral vessels carrying food to us in as rapid succession as he can discover them. But if the Declaration is not passed, cannot he do so equally?

Admiral Sir E. R. Fremantus :-No.

Major Johnson :-Why not?

Admiral Sir E. R. Frbmantle :-We have protested strongly.

Major Johnson:-Well, I should like to know whether the mere fact of Great Britain's protesting strongly against a view which is held and a right which is maintained by all the other maritime Powers-

Admiral Sir E. R. Frementle :-No, that is not so.

Major Jorsson:-Surely that is the position. The right to sink is maintained by Germany, the United States, Austria, France, Italy, Russiapractically every big naval Power except Japan. ${ }^{1}$.

2 Cp. Blue Book, C.D. 4555, Proceedings of London Naval (onference, pp. 99-102. 
Admiral Sir E. R. Fremantlx:-Can you give me any instance?

\section{Major Josnson:-How was it with the Knight Commander?}

Admiral Sir E. R. FaExANTLE:-That is the only instance that you can give me.

Mr. Owes:-Perhaps I can assist in this matter. In Sir Edward Grey's Letter of Instructions to Sir Edward Fry of the 12th of June. $190 \%$, at the second Hague Conference, he said "As regards the sinking of Neutral Prizes, which gave rise to so much feeling in this country during the Russo-Japanese War, Great Britain has always maintained that the right to destroy is confined to enemies' vessels only, and this view is favoured by other Powers. Concerning the right to destroy captured neutral vessels the view hitherto taken by the greater Naval Powers has been that in the event of its being impossible to bring in 2 vessel for adjudication she must be released. You should urge the maintenance of the doctrine upon this subject which British Prize Courts have, for at least two hundred years, held to be the law." Those are Sir Edward Grey's words.

Major Johnson:-With all due deference, it seems to me that we have here a fundamental misunderstanding. The whole emphasis is laid by Mr. Owen upon the fact that the British Prize Courts have for two hundred years maintained this right.

Admiral Sir E. R. Frenantus:-And others, too.

Major Jounson:-Practically only by Japan, and surely the whole. asgument in Mr. Gibson Bowles' book is that these Clauses have been introduced into the Declaration of London on the action and by the evil suggestion of the Continental Powers, Land Porers versus Sea Power. If that is so, we have hero not a new view invented by them ad hoc. but a view which they have maintained in the past.

Mr. Gibson Bowles:-Do you not see the difference between a gentleman asking you for your watch and you giving it to. him?

Major Jounson :-Mr. Bowles' parable would only be applicable if the law of the town in which I lived regarded theft as theft, while the law of the street in which the gentleman met me did not. The real question is: Is Germany going to ask America for her' watch when she is at war with England, and is America then to give it to her? What will America say? Is Germany when at war with us going to sink ship after ship belonging to the United States carrying conditional contraband to Great Britain? There are two parties interested in that action. The first and most important of all is ourselves, and we have said in the Declaration of London that wo will leave the question as to whether the ship was sunk under extreme and exceptional military necessity or not to an International Court. But we still stand exactly by the position we aldays stood by, namely, that the neutral vessel carrying non-contraband of war should not be sunk at sea, except under extreme military necessity, but, if sunk, must be paid for in full. There is this further point, that the other party who is interested is the powerful neutral, the United States of America. Do we for a moment suppose that the great neutral is going to allow Germany to sink ship after ship 
carrying contraband of war even "absolute" still more "conditional "?

Mr. OwzN :-If she signs the Declaration she will have to.

Major Jornson:-Not so; there could not possibly be military necessity in every case; on the first case the United States would appeal : to the International Courts, on the second she would go to war, International Court or no. I come back to my original point. I want to get clearly in my mind what is the present position with regard to all these things. : What, is the present actual position as regards the sinking of neutral ships at sea, not by us, but by our encmies in time of kar? What is the present position. as regards their converting merchantmen into war ships on the high seas? Mr. Gibson Bowles made a slip, I think, when he told us we had agreed to that. . I take it he means tacitly. agreed to it. But if we have not agreed to it, but have exprossly said we cannot so agree, I fail to see where the "tacit" part of the business comes in. . Our position remains exactly where it was. If we were at war and found a neutral merchantman on the high seas at "work as a wai ship we hould sink her as a pirate, and the Declaration of London does not alter that position. No doubt it would have altered the position enormously if wo had been able to induce the other maritime Powers-and this is the kind of point which underlies the whole broad question - to take our. view on the subject and to declare that this practice should not continue. If we had been able to do that we should have gained a great victory. However, as we wero not able to do that, I do not see clearly how the Declaration of London has given away that right which we have always maintained.

Admital Sir E. R. FrRnantLe :-Because we have made no protest.

Major Jounson:-We reserve, the protest, and I fancy, Sir, that if you have anything to do with the control of flects when war comes, your protest will be vigorous and quite sufficiently effective. The main point I wanted to put before you, is that, so. far as I can see, if we study these articles one by one and compare them, not only with the present chaotic condition of international law on the point, but with our own British maritime law as interpreted by our own British Pribe Courts, we shall see that, not only, have we abandoned none of the rights that remained to us after the signature of the Declara. tion of Paris, but in addition to that we have gone an enormous way towards getting the Ncutral Powers to accept our ou'n law. I fancy all of us here present are rather actuated by the feeling that we might have compelled all Europe to take precisely the same view in connection with the whole of these maritime questions as our: Naval: Prizo Courts do at this moment. That would have been a splendid thing. That we have failed in some respects to persuade them to take that view is regrettable, but hardly to be wondered at. That we have succeeded in many. important particulars in persuading them to take exactly the view our own Naval Prize Courts would do is, I think, a very great feather in our cap. There are certain questions which are reserved, questions which are not affected at all by the Declaration of London. There are certain other questions in. which it is true we have made very slight concessions. The real question is whether these concessions are, as I claim, very slight, or whether they are so grave as to make it necessary that we should still leave the law at sea in the condition of uncertainty 
in which it at present stands. If the latter is the position, then we shall only have two alternatives, whether as a great neutral or as a belligerent, when there is a question at issue between us and another Power. Either we must declare war on that Power, which may bo much norse than awkward, when we are already engaged in war with a sufficiently serious enemy, or nie must do as we did when the Knight Commander was sunk-write Foreign Office letters for about three years and then say nothing more about it I

Mr. Douglas OWs, in reply:-With the exception of the remarks of the last speaker. I think I have very little to reply to. Mr. Gibson Bowles, I believe, rather misunderstood me when he thought that I said that the altered conditions would prejudice us as a naval power. I did not say that, or at any rate, I did not mean it. I am quite in accord with the view he expressed. As regards panic, Mr. Gibson Bowles and I do not agree, and I am sorry that I cannot agree with him, as I would be only too. glad to do so. His opinion also is against that of the Chambers of Commerce and business men in the City. More than that, he is in the minority as compared with the conclusion deliberately arrived at by the Royal Commission on Food Supplies. The Royal Commission at the conclusion of their Report say: "We have to take into consideration the possibility of a panic hampering Government action in time of war." Their report refers to the panic which affected the disposition of the American feet in the Spanish war, and says: "It is therefore neither unreasonable nor unjust to our people to apprehend that, n.ith more reason, due to our dependence on overseas supplies, it will be likely to exercise pressure to the embarrassment of those responsible for the conduct of war." I entirely agree with Admiral Tupper; I think it is to be regretted that we have no system or organisation dealing with the possibility of a panic, and I think one ought to be promoted. With regard to Major Johnson's defence of the Foreign Office, the point that presents itself very stronglo. ${ }^{+n}$ me is this, and $y$ will illustrate it by a concrete example. As we stand now, putting the seciaration on one side, say we are at war with a Continental Power. America has the right, and would certainly assert the right, of shipping to Bristol and Cardiff supplies of food, and she would deny the right of our enemy to interfere with those supplies. The result of that under the existing - law would be this:-It is extremely improbable that our Continental enemy would dare to interfere with American neutral supplies coming to us. The Americans would resent it, and their poperful fleet would be at once prepared to back up their mercantile marine. Under the Declaration of London we are entirely giving away that position. We are signing, and we are asking America to sign, an Agreement that if we should be at war with a Continental. Power, and that Continental Power should sink Amcrican ships carrying food supplies to Cardiff or to Bristol, America should have no right to protest. All America can say is-" Woll, you must go: on, if you think it is right, sinking these supplies. We admit that the Declaration of London gives you that power, and we shall appeal after the war is, over to the International Prize Court."

Major Jonnson: Do you seriously suppose, Sir, that the United States would actually do that? Do you think they would allow fifty ships one after the other to be sunk in one day? Do you really mean that the 
United States of America, after one ship had been sunk and they had appealed to the Court, if on the next day they heard that fifty ships in succession had been sunk, the United States of America would not say they were not going to have that going on while the adjudication was going on?

\section{Mr. Douglas Owen:-Certainly.}

Major Johnson:-Then that is where we differ.

Mr. Douglas Owen :-America would be bound by the Declaration; she would have no right to interfere. That is where we differ essentially and strongly. I have to thank you, ladies and gentlemen, for. the attention which you have been good enough to give mo.

The Chairman (Admiral Sir C. A. G. BRIDGE):-We have been sitting a considerable time, and I do not suppose anybody wishes to remain very much longer, and therefore the remarks I have to make will necessarily be few. It is natural that if there is anything likely or supposed to be likely to touch our maritime position in war it should receive very much attention in this country. There are, to begin with, important and influential sections of the community who are immediately interested, viz., importers of food and raw materialo-the shipowners, millers, insurance companies; but far beyond the interest that they have is the interest of the very much larger class, viz., people of the. weokly wage-arning working class. To them it is a question that is really vital. The Lecturer has drawn in one section of his lecture a very lurid picture of what we may expect to be the case when we are at war after the Declaration of London has been accepted by this country; and Admiral Tupper also has referred to that. I think. it would be as well before taking any steps with regard to the conservation of stocks of food in this country, and the storage of food to read the evidence that has been given before more than one Royal Commission which has considered the subject in the last few years. One of the fist things that will have to be sottled is how long the war is going to last. Is it going to be a matter of a few weeks or a few months; or is it, as in most wars in which this country has been engaged, going to last for several years? If so, what arrangements should you make for the storage of food, the whole presumption on which you desire to store it being that the conveyance of it td your shore is interrupted or prevented altogether. Of course this whole question ought to have an impartial investigation. 1 do not mean impartial as opposed to unfair; but investigation which will show the two sides of the case; which does not merely prosent the reak points and strong points of one side and leave out the weak and strong points of the other side. Another thing is that when history is appealed to it should be correct; also when figures. are given they should be accurate, and where inferences are drawn they should be reasonable and at the same time fairly. obvious to the people who listen to what is said. With regard to history, the Lecturer said that we did not go to war on account of individual traders. I am afraid that would be hardly borne out by our history. To take an instance far cnough back to be no longer a contentious matter, the "War of Jenkins's Ear," I was so impressed by it that I copied what Professor Seely said on the subject: "Commerce sometimes makes for peace; but, given the circumstances suitable to it, it very often makes for war." I 
think it will bo found that a very large proportion of the great maritime wars in which we have been engaged were brought about by questions of commerce.

Mr. Gibson Bowlas : All of them.

The Chatruan :- It appears to be thought, and the Lecturer is of that opinion, that our dependence upon imported food from across the sea is modern. As a matter of fact hundreds of thousands of the people in this country depended upon forcign grown corn brought by sea to this country between the years 1800 and 1815 . With only about a quarter of the population that we have now in Great Britain, over $850,000-$ and if you are to take the proportion of corn which we consume now an even larger number than that-depended solely on foreign corn for their food. There fore, this is no new thing. During our great war between 1792 and its - definite conclusion at the Battle of Watcrloo, our importation of cottonraw material which we cannot produce here-increased between three and four-fold. Therefore circumstances then were to some extent such as we have them now. No doubt in degree they are aggravated, if you like to put it so. . Then it is belicved, and I notice that the Lecturer is of that opinion, that foreign nations in the matter of food are practically selfsupporting or nearly self-supporting. Only last Saturday there was a very interesting letter in the Spcciator by Mr. Edward Paul, who gave some remarkable figures. There is a suggestion of them in Mr. Douglas' Oweri's lecture. In 1999 , in the four ports of London, Liverpool, Bristol and Cardiff, we imported 14,073,000 quarters of wheat. In the two ports mentioned by the Lecturer, Antwerp and Rotterdam, they imported 15,886,000 quarters of wheat. Therefore those two ports imported considerably more than we did in four; and accordingly we may start with the view. that for us to be dependent on foreign foodstuffs brought to us during war is not a new condition; and we may also note the fact that the new condition is that foreign nations, with some of whom we may be at war; are dependent on foreign foodstuffs in a way they never wero at the beginning of the last century. I think perhaps Mr. Gibson Bowles, on the question of panic, has dealt indirectly with the question of price. In his book he gives us some very interesting figurrs. He says that in September, I792, before the Great War, wheat in England was 535. 4d. per quarter; but in September, 1793, when the War had been going on seven months; it had fallen to $45 \mathrm{~s}$. He goes even further than that because he show's that the very high price of wheat-I think about three times as much as the last quoted-occurred two years after the Battle of Waterloo. What is more significant, arid I think more relevant to the present question, is that in the late South African War,-although freights rose all round from 50 to 100 per cent.-and this deals with one of the subjects mentioned by one of the speakers-the price of wheat fell from 2;s. 4 d. in October, 1899 , to $26 \mathrm{~s}$. IId. for the whole of the yean 1900. Those things should be taken into consideration, as they may tend to alleviate the terror which would be inspired if we took the picture which. is drawn, not by the Lecturer alone; but by several of the speakers as to the condition this country would be in when we go to war. We should, of course, be dependent for our food supply and for everything that comes to this country upon British shipping and neutral shipping. Somebody just now read an extract from one of the letters of one of the Chambers of commerce-indeed I read it myself somewhere-to this effect: "We may be able to defend our onn shipping on the sea, but how are we 
going to defend the noutral shipping?" A more extraordinary failure to appreciate what naval warfare is 1 do not think it is possible ro. conceive. It would be a deeply interesting thing if one" could peer into the mind of the person who penned that sentence. 'Uhere it is important is that it represents the objections raised to the Declaration of London by almost everybody who is objecting to it. To my mind, and to the minds of other people who have studied the question of naval warfare and what the position of this country would be, that is very alarming, because it shows us that there is an entirely mistaken view. as to the position of the country in.time of rar. Look at this curiously significant fact. In this Lecture which we have listened to to-day with such great interest, and which' I may say in the prosence of the Lecturer and without any false praise, is an extremely able and well considered document, the Lecturer has performed the really remarkable achievement of writing nearly sixteen pages of small print on the question of the supply of food to this country in war, and the British Navy is never alluded to from the beginning to the end. There is not one single allusion to it. There is a mention of the fact that two of our naval officers were connected with the Declaration of London; but beyond that there is absolutely no allusion to the existence of the Navy at all. Naval officers are frequently mentioned, but they are always foreigners. What is the view that the British Navy will be about when these foreigners are doing all the remarkable things we are told they are going to do in this Lecture? Whero this matter is so important; so momentous, is that it is evidently a very widespread view. Chambers of Commerce all over the kingdom, and indeed, as Mr. Wyatt said, all over the Empire, would not put forward the views they do if they did not hold opinions which are more or less represented by what I have just tried to describe. The first thing it is desirable that people should get into their minds, whether they belong to Chambers of Commerce or whether they do not, is that war is a game at which two can play; and our policy is not to sit down and allow other people to play the game as they like, bus as Mr. Gibson Bowles very clearly and forcibly put it, to prevent them from playing any game at all. If we do that, neutral shipping bringing commodities to this country will be quite as safe as our own; and that thoy vill be practically safe I think has been proved by our previous history. If it is impossible to get the public and those representative and important portions of the public who constitute Chambers of Commerce, and infuential bodies of that sort, to realise what the conditions of naval warfare really are and what they specially are for an insular State like this, it seems almost like pouring water into a sieve to discuss the Declaration of London or any other International Agrcement. It looks as though people were of opinion first of all that we should stand on the defensive and that we should detend ourselves with pieces of foolscap paper. That is no imagination on my part. I think I can give you word for word an expression used in one of the letters of one of the Chambers of Commerce. It finds fault with the Declaration for recognising the fact that if wo are at war we shall have to depend for our existence on our own right arm ! In the name of heaven, what else are we to depend upon? I nention those things to show how very far from an appreciation of the real state of things people in these very importanit positions are; and I think we ought specially to thank Mr. Douglas Owen, not only for giving us a Lecture of great interest which will make all of us think a great 
deal, but also for having brought into a strong light how commoin that opinion is amongst people who are, as I say, in important and influential positions. We ought to thank him for warning us of a danger not threatened by any onemy but growing up in our own midst.

Major-General Sir T. FrASER, who, owing to the late hour to which the discussion was extended, did not find the opportunity to speak, has sent the following noto of his intended remarks :-

1 noticed at the lecture of the i8th on the Declaration of London, a feeling, to which expression was given, that after all we could, when it was ratified, tear it up in war. It was so late I refrained from delaying the ending, but $I$ desire to say that we cannot tear up Treaties without damaging discredit. The last two great European settlements were in part torn up, and whatever may have been the source that instigated the acts, the cnsequences have still to be reckoned with by the perpetrators. The example of "I'unica Fides" on the part of our great noval prototype, did not save Carthage in the end. Why, when ne are free now, should we handcuff ourselves and invite friendly nations to do so too, to please a certain "Continental "desire for "uniformity," which is rather a "conformity" to what suits them best? We may, perhaps, reckon on breaking loose to our own injury; but will friendly nations do so to oblige us? Better stand fast, and " never give up anything." 